\title{
Valorization of The By-Products of Poultry Industry (Bones) By Enzymatic Hydrolysis and Glycation to Obtain Antioxidants Compounds
}

Luisa María Londoño Zapata ( $\square$ luisa.Iondonoz@udea.edu.co )

Universidad de Antioquia https://orcid.org/0000-0001-9192-9277

\section{Sara Franco Cardona}

Universidad de Antioquia https://orcid.org/0000-0002-0198-6516

\section{Sandra Patricia Restrepo Manotas}

Universidad de Antioquia https://orcid.org/0000-0003-2797-0253

\section{Fáver Gómez Narváez}

Universidad de Antioquia https://orcid.org/0000-0001-9800-8147

\section{Lina Marcela Suárez Restrepo}

Universidad de Antioquia https://orcid.org/0000-0003-2784-314X

\section{Helena Nuñez Andrade}

Universidad Técnica Federico Santa María https://orcid.org/0000-0002-6168-451X

\section{Pedro Valencia Araya}

Universidad Técnica Federico Santa María: Universidad Tecnica Federico Santa Maria https://orcid.org/0000-0003-2422-1548

\section{Ricardo Simpson}

Universidad Técnica Federico Santa María: Universidad Tecnica Federico Santa Maria https://orcid.org/0000-0002-6040-4387

\section{Oscar Vega Castro}

Universidad de Antioquia https://orcid.org/0000-0003-3517-9760

\section{Research Article}

Keywords: Chicken bones, enzymatic hydrolysis, glycation, antioxidant, HMF and furfural

Posted Date: November 16th, 2021

DOI: https://doi.org/10.21203/rs.3.rs-972845/v1

License: (a) (1) This work is licensed under a Creative Commons Attribution 4.0 International License. Read Full License 
22

\section{VALORIZATION OF THE BY-PRODUCTS OF POULTRY INDUSTRY (BONES) BY ENZYMATIC HYDROLYSIS AND GLYCATION TO OBTAIN ANTIOXIDANTS COMPOUNDS}

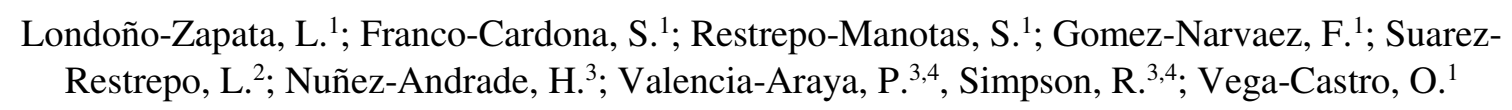

2. Department of Food, Faculty of Pharmaceutical Sciences and Food, Universidad de Antioquia, Medellin, Colombia.

3. Department of Chemistry and Environmental Engineering, Universidad Técnica Federico Santa María, Valparaíso, Chile.

4. Centro Regional para el Estudio de Alimentos Saludables (CREAS) Conicyt-Regional R06I1004, Avenida Universidad 330, Valparaíso, Chile.

Correspondence should be addressed to:

Ing. Luisa María Londoño-Zapata

Phone: $+57+3148291486$

E-mail: luisa.londonoz@udea.edu.co

1

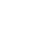
3 4

5
6 7 8 9 0 1 2 3

$$
\text { To be submitted to: }
$$

Waste and Biomass Valorization

October 2021 


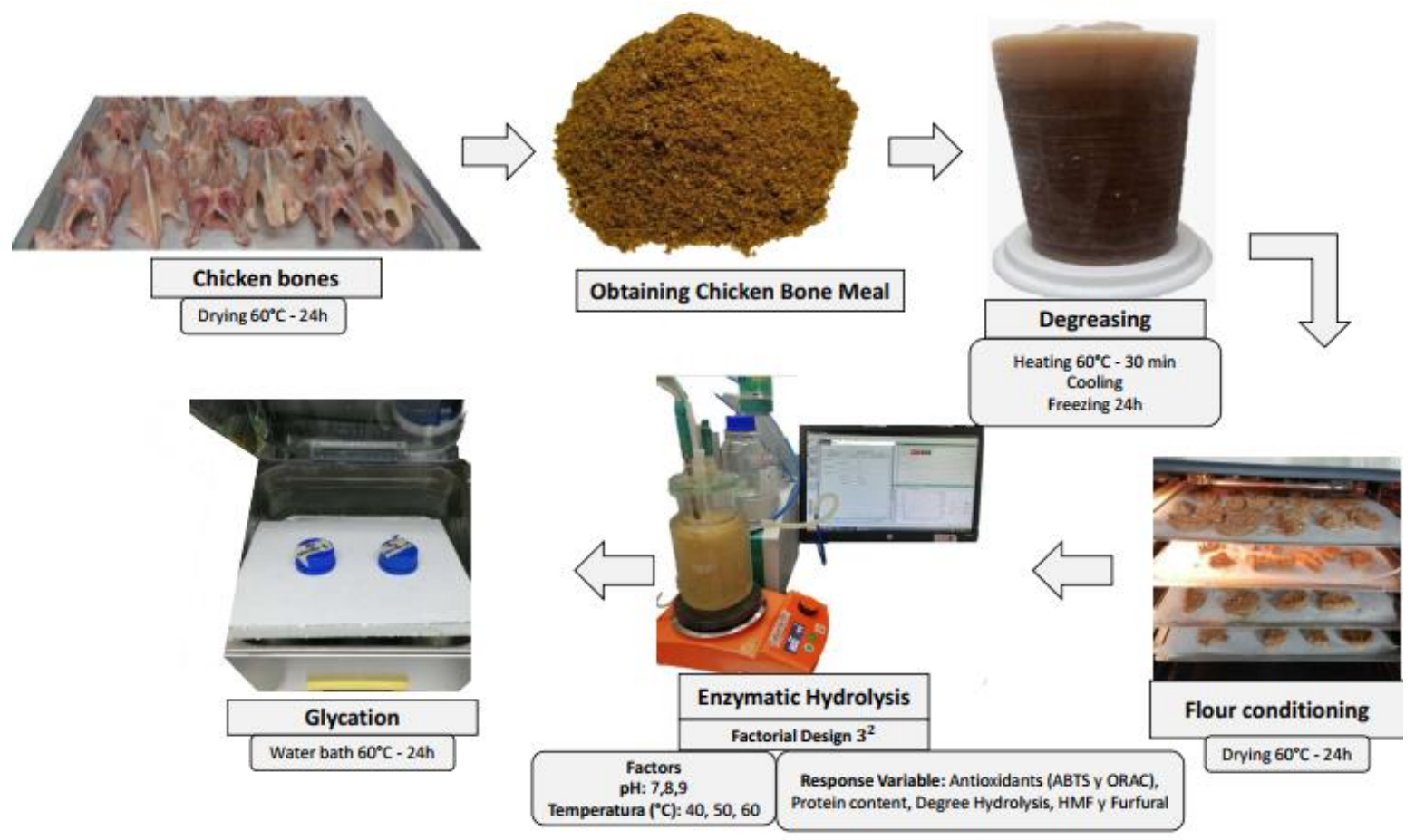

\section{Abstract}

Currently, one of the fastest growing industries in the world is the poultry industry; however, the increase in demand has generated the production of various byproducts, such as bones, and these byproducts have a negative impact on the environment. The aim of the present work was to evaluate the effect of glycation on the increase in antioxidant compounds and the formation of indicators of advanced glycation end products (AGE) in chicken bone hydrolysates; it also aimed to maximize the protein content, degree of hydrolysis and antioxidant content. Through analysis of variance (ANOVA), the content of AGE products (HMF and furfural) formed in the glycation process was analyzed. The chicken bone hydrolysate $(\mathrm{CBH})$ had a protein content of $1.42 \mathrm{~g} / \mathrm{l}$, a degree of hydrolysis of $17.2 \%$ and an antioxidant capacity of 8334 and $10343 \mu \mathrm{mol}$ ETrolox/1 according to ABTS and ORAC evaluations, respectively. The glycation process increased the ORAC by $6.57 \%$. The presence of hydroxymethylfurfural and furfural was determined in the glycated samples and detected at values between 0.05 and 0.22 and 0 and $0.26 \mathrm{ppm}$, respectively. In conclusion, hydrolysis and glycation are suitable alternatives that enable the use of chicken bones in producing food ingredients with higher added value.

51 Keywords. Chicken bones, enzymatic hydrolysis, glycation, antioxidant, HMF and furfural.

53 Statement of Novelty: The novelty of this study lies in obtaining compounds with antioxidant 54 activity through enzymatic hydrolysis and glycation, evaluating the formation of indicators of 55 advanced glycation end products in chicken bone hydrolysate to obtain a functional product with 56 potential applications in the food industry, proposing an alternative that can reduce the environmental 
impact of this waste product, which has a high content of nutritional protein that can be used to obtain bioactive compounds through enzymatic hydrolysis and glycation.

\section{Introduction}

Currently, the world consumption of chicken meat grows on average by $2.6 \%$ per year [1]. By 2030, the consumption per capita in the world will be $17.2 \mathrm{~kg}$ [2]. However, the increase in the consumption of chicken in its different forms and products generates a variety of byproducts, including viscera, legs, heads, bones, feathers and blood, which are approximately $37 \%$ of the live weight of the animal [3]. These byproducts have various impacts on the environment when the industry does not dispose of them properly [4], which leads to biological and biosafety problems [5]. The main poultry meatproducing countries in the world are the United States, Brazil, the European Union and China, which generate $20.3,14.0,12.8$ and $12.3 \%$ world production, respectively; the remaining $40.6 \%$ of poultry products are produced in other countries [6]. On the American continent, Colombia ranks fifth with a production of 1.5 million tons of chicken meat per year, below the United States, Brazil, Mexico and Argentina [7].

The increase in the consumption of chicken meat worldwide is due to factors such as low cost, a lack of religious limitations, ease of accessibility, ease of transformation into processed foods [8], and its sensory and nutritional properties [9]. Chicken meat is recognized for its various health benefits, such as its low contents of cholesterol, calories and fat [10]; chicken meat also has a high content of proteins with high biological value [11], as well as essential amino acids and unsaturated fatty acids necessary in the human diet [12].

Given the quantity of production described above, several alternatives have been sought for the use and valorization of the byproducts of the poultry industry to mitigate its environmental impact. For example, the use of chicken feathers [13] and chicken hemoglobin powder [14] in animal food preparation has been reported. In addition, it has been determined that chicken feathers are an important source of amino acids for pigs [3]. Other studies have investigated the production of methane [15], biodiesel [16], flavorings and flavor enhancers from chicken blood, meat and bones [17].

However, one of the most interesting applications of the byproducts of the poultry industry is their use in the extraction of biomolecules, such as polyunsaturated fatty acids and proteins, by enzymatic hydrolysis [18]; chicken bones have specifically been used in this application due to their high protein content of approximately 19\% [19]. These components have applications in the pharmaceutical, cosmetic, nutritional, food and microbiological industries [18] and have potential for application as functional ingredients [13]. In general, enzymatic hydrolysis has been used to obtain antioxidants from proteins of various sources, such as wheat germ [20], black beans [21], turkey byproducts [22], salmon gelatin [23] and chicken blood [24]. The extraction of antioxidant peptides derived from food proteins has provided natural ingredients for the formulation of functional foods and has improved their quality [25].

In addition, a prior study [19] determined that once antioxidants are obtained from proteins, they can be increased through a process known as glycation, the reaction between a reducing sugar and the amino acids that come from the peptides released during hydrolysis of the sample, from which the compounds derived from the last stages of the Maillard reaction are formed. [26]. Various authors 

[27] and whey [28].

101

102

103

104

105

106

107

108

109

110

111

112

113

114

115

116

117

118

119

120

121

122

123

124

125

126

127

128

129

130

131

132

133

134

135

136

137

In addition, it has been reported that the antioxidant activity of compounds derived from glycation is due to different mechanisms, such as the chelation of metal ions, breaking of radical chains, decomposition of hydrogen peroxide and elimination of reactive oxygen species [29].

Recent studies report enzymatic hydrolysis as an alternative for the valorization of byproducts of the food industry [25], [30]; however, few studies have reported on the effect of glycation in these hydrolysates. This work aimed to evaluate the effect of glycation on the antioxidant capacity and the formation of indicators of thermal damage in $\mathrm{CBH}$ to obtain a product with potential applications in the food industry and generate an alternative to mitigate the environmental impact of this waste.

\section{Materials and methods}

\section{Materials}

Chicken bones (Carcasa) were purchased from a local market (Supermarkets EURO). The enzyme used was ALCALASE 2.4L® (Novozymes, Denmark), which contains subtilisin from Bacillus licheniformis. Its optimal temperature is between $55^{\circ} \mathrm{C}$ and $70{ }^{\circ} \mathrm{C}$, depending on the substrate, and the optimal $\mathrm{pH}$ is between 6.5 and 8.5 [31].

All reagents were of analytical grade and commercially available. Bovine serum albumin, fluorescein sodium, 2,2'-azino-bis(3-ethylbenzothiazolin)-6-sulfonic acid (ABTS), 6-hydroxy-2,5,7,8tetramethylchromane-2-carboxylic acid (Trolox), and AAPH (2,2'-azobis(2-amidinopropane) dihydrochloride) were obtained from Sigma-Aldrich, St. Louis, MO, USA, and the phosphate buffer solution was prepared with reagents from MERCK®, Germany.

\section{Sample treatment}

For the treatment of chicken bones, the methodology described in a pervious study [32] was followed, with some modifications. The chicken carcass was conditioned by removing the adhered meat. The bones were dried in a convective dehydrator (Estructuras y Montajes SAS, Colombia) at $60{ }^{\circ} \mathrm{C}$ for 24 hours. Once the bones were dried, they were crushed in a Nutribullet food processor at maximum power for approximately 2 minutes (Nutribullet $600 \mathrm{~W}$, USA).

\section{Degreasing and drying of flour}

Once the bone meal was obtained, it was mixed with distilled water at a ratio of 1:3; the solution was heated to $69{ }^{\circ} \mathrm{C}$ for 30 minutes with constant stirring; then, it was cooled to a temperature of $60{ }^{\circ} \mathrm{C}$ and refrigerated (Lassele, Mixed Refrigerator LRF-1382PC, Korea) until a temperature of $40{ }^{\circ} \mathrm{C}$ was achieved. Once this temperature was reached, the mixture was distributed in $250 \mathrm{~mL}$ polypropylene beakers, frozen for 24 hours, and stored in a freezer at a temperature of $-18{ }^{\circ} \mathrm{C}$ (Lassele, LRF-1382PC Mixed Refrigerator, Korea). Subsequently, the sample was removed from the beakers, and the layer of suspended fat on top of the sample was cut. Once the sample had been degreased, it was cut by a chopper into blocks with an approximate thickness of $1.5 \mathrm{~cm}$ (Braher, Spain, Tajadora USA-250 Mono), and these were placed in a convective dehydrator (Estructuras y Montajes SAS, Colombia) at $60{ }^{\circ} \mathrm{C}$ for 24 hours.

\section{Chemical characterization of flour}


The proximal analysis of chicken bone meal was performed according to AOAC methods [33], and moisture, protein, fat, ash, and carbohydrates were determined by difference. All tests were done in triplicate. See Table 1.

\section{Enzymatic hydrolysis}

For the enzymatic hydrolysis process, the methodology provided in a published study [34] was followed with some modifications. Initially, chicken bone meal was diluted in distilled water in a 500 $\mathrm{mL}$ glass reactor at a protein concentration of $20 \mathrm{~g} / \mathrm{L}$. Hydrolysis was evaluated at 40,50 and $60{ }^{\circ} \mathrm{C}$ and at $\mathrm{pH} 7.8$ and 9. The apparatus was controlled with sensors connected to a Titrando 842 autotitrator (Metrohm, Switzerland) operated by a computer (Tiamo 1.2.1 software) that maintained the constant stirring of the reaction.

Once the $\mathrm{pH}$ and temperature conditions of the experimental design were reached (Table 2), Alcalase $2.4 \mathrm{~L}$ food grade was added to start the reaction. The hydrolysis process was carried out over 2 hours [35]. The base volume spent was recorded, and the degree of hydrolysis was calculated with the $\mathrm{pH}$ stat method, according to a prior study [36]; the released amino - $\mathrm{NH}$ groups were calculated according to Equation 1, and the average degree of dissociation was calculated according to Equations 2 and 3:

$$
\begin{gathered}
\% D H=\frac{V_{B} \times N_{B} \times 1 \times 1}{M_{p} \times \alpha \times h_{t o t}} \times 100(1) \\
\alpha=\frac{10^{p H-p K}}{1+10^{p H-p K}}(2) \\
p K=7.8+\frac{298-T}{298 \times T} \times 2400(3)
\end{gathered}
$$

where $V_{B}$ is the volume of base consumed in $\mathrm{L}, N_{B}$ is the normality of the base $(\mathrm{N}), \mathrm{Mp}$ is the mass of the protein in $\mathrm{kg}, h_{\text {tot }}$ is the total number of peptide bonds in the sample (eq/g protein) (for chicken proteins, its value is 7.6.), and $\alpha$ is the average degree of dissociation of the $\alpha-\mathrm{NH}_{2}$ groups released in the reaction, which depends on the $\mathrm{pK}$, which in turn is a function of temperature, as indicated in Equations (2) and (3) [37]. Finally, the solution was heated at $85{ }^{\circ} \mathrm{C}$ for $10 \mathrm{~min}$ while stirring to inactivate the enzyme and stop the reaction.

\section{Protein content}

The protein content of the hydrolysate was determined by the Bradford method [38], [39]. The standard curve was made with bovine serum albumin. The absorbance was measured at $20^{\circ} \mathrm{C}$ at a wavelength of $595 \mathrm{~nm}$ using a Thermo Scientific ${ }^{\text {TM }}$ Varioskan ${ }^{\text {TM }}$ LUX multimode microplate reader.

\section{Glycation Process}

The glycation methodology described in an earlier report[40] was followed; depending on the final protein content of the supernatant obtained from the hydrolysate by the Kjeldahl method, powdered lactose was added in a 1:1 protein mass ratio (Protein:Lactose). This solution was heated in a water bath (Lauda; Aqualine AL 5; Germany) at $60 \pm 2{ }^{\circ} \mathrm{C}$ for 24 hours. Once this process was finished, the product was frozen and stored (Lassele, LRF-1382PC Mixed Refrigerator, Korea) until further analysis.

\section{Antioxidant activity}

The antioxidant activity of the hydrolysate supernatant and glycated samples was determined by two methodologies: ORAC and ABTS, which are described below. 
177 First, $150 \mu \mathrm{L}$ of fluorescein sodium working solution and $25 \mu \mathrm{L}$ of the sample were added. For the blank, $25 \mu \mathrm{L}$ of $75 \mathrm{mM}$ phosphate buffer ( $\mathrm{pH} 7.4$ ) was added to the microplate. The samples were incubated for 30 minutes at $37{ }^{\circ} \mathrm{C}$. Subsequently, $25 \mu \mathrm{L}$ of AAPH (2,2'-azobis(2-amidinopropane) dihydrochloride) solution was added and shaken for 10 seconds at maximum intensity. The fluorescence intensity was measured every 5 minutes for 2 hours at excitation and emission wavelengths of $485 \mathrm{~nm}$ and $528 \mathrm{~nm}$, respectively.

183

184

185

186

The ORAC values were calculated from the area under the curve of the sample data, and the results were expressed in micromoles of Trolox equivalents per L ( $\mu$ Mol ETrolox/L) [39-41] according to Equation (4):

$$
O R A C=\left[\left(A U C-A U C^{\circ}\right) /\left(A U C_{\text {Trolox }}-A U C^{\circ}\right)\right] \times f(\text { Trolox })
$$

where AUC is the area under the curve for the sample, $A U C^{\circ}$ is the area under the curve for the control, $A U C_{\text {Trolox }}$ is the area under the curve for Trolox, and $\mathrm{f}$ is the dilution factor of the extracts.

\section{ABTS}

One hundred microliters of the sample or Trolox standard was taken for the blank, mixed with $1 \mathrm{ml}$ of the ABTS solution, and incubated at $30{ }^{\circ} \mathrm{C}$ for $30 \mathrm{~min}$. After that, absorbance measurements were performed at $730 \mathrm{~nm}$. Aqueous solutions of Trolox with concentrations between 0 and $500 \mathrm{M}$ were used for the calibration curve. The results are expressed as micromoles of Trolox equivalents per liter $(\mu \mathrm{Mol}$ ETrolox/L) according to a prior study [27] with some modifications.

\section{HMF Y Furfural}

HMF and furfural compounds were determined as described in a previous study [44], with some modifications. Four milliliters of the homogenized sample was taken and diluted in $2 \mathrm{~mL}$ of water, clarified with $250 \mu \mathrm{L}$ of Carrez I and II, and centrifuged for 10 minutes at $5000 \mathrm{rpm}$ three times. Subsequently, it was filtered, and a volume of $10 \mathrm{~mL}$ was obtained. The supernatant was then passed through a filter with a pore size of $0.2 \mathrm{~mm}$, and $50 \mu \mathrm{L}$ of the filtered sample was analyzed on a $\mathrm{C} 18$ column at a rate of $1 \mathrm{~mL} / \mathrm{min}$ with a mobile phase of water:acetonitrile (95:5) and a wavelength of $284 \mathrm{~nm}[45]$. The analyses were performed in duplicate.

\section{Experimental design}

A factorial design of $3^{2}$, with 3 center points, was carried out. The hydrolysis temperature and $\mathrm{pH}$ were the independent variables, and the protein content, degree of hydrolysis (DH), and antioxidant content by ABTS and ORAC were the dependent variables. This design was performed on hydrolyzed chicken bone meal samples. Each factor was studied at three levels (see Table 2). The design values were evaluated by analysis of variance (ANOVA) to determine the possible significance of the independent variables and their effects on the dependent variables. The experimental trials were randomized to reduce the results of unexpected variability in the observed responses. To find the optimal enzymatic hydrolysis conditions and to analyze how the independent variables affected the overall response, regression analyses and response surface plots were generated. The response variables that were found to be significant in the study were optimized.

The effect of glycation on antioxidant content and the formation of thermal damage indicators was evaluated by analysis of variance (ANOVA) as a function of the glycation process; the antioxidant, HMF and furfural contents were considered the response variables. The samples analyzed by this 
design were those subjected to hydrolysis and subsequent glycation processes. The data were analyzed with Statgraphics Centurion XVI version 16.1.03 software.

\section{Results}

\section{Characterization of chicken bone meal}

Table 1 shows the results obtained from the proximal characterization of chicken bone meal. These values are similar to those reported by the Spanish Foundation for the Development of Animal Nutrition [44-47], which obtained protein content values of 49.3, 55.45, and 43\%, respectively, for chicken bone meal. Several authors have also determined the protein contents in blood [50], offal [51], and chicken feet [52], and the values change depending on the part of the chicken used and can range from 20 to $60 \%$. The contents of other components, such as ash, moisture, fat, and carbohydrates, are reported in Table 1.

\section{Effect of hydrolysis conditions on the content of antioxidants, protein, and degree of hydrolysis} of chicken bones.

Table 2 shows the experimental design, as well as the results of the variables analyzed, while Table 3 shows the significance levels for each of the factors and their interactions, as well as the coefficients of determination $\left(R^{2}\right)$. Fig. 1 shows the response surface graphs for each variable.

\section{Protein content}

Table 2 presents the protein content in the $\mathrm{CBH}$; the results varied between 0.84 and $1.65 \mathrm{mg} / \mathrm{mL}$ of protein; these results varied because the limited hydrolysis allows for alterations in the molecule size and the structure and strength of intermolecular and intramolecular interactions between proteins; the molecules are separated into peptides and free amino acids, decreasing the protein content and indicating structural changes [53] that confer functional properties, such as antioxidant activity, to the hydrolysates [54].

According to Table 3, temperature and $\mathrm{pH}$ had a significant effect $(\mathrm{p}<0.05)$ on the protein content. Temperatures close to $50{ }^{\circ} \mathrm{C}$ allowed a higher enzymatic activity for hydrolysis [53-54], which is evidenced by the decrease in protein content with increasing temperature.

\section{Degree of hydrolysis}

Table 2 shows that the degree of hydrolysis (DH) ranged from 13.59 to $17.98 \%$, and similar values of $\mathrm{DH}$ have been reported in a previous study [35] on salmon byproducts.

According to Table 3, DH was significantly affected by $\mathrm{pH}(\mathrm{p}<0.05)$; a higher $\mathrm{DH}$ was obtained with increasing $\mathrm{pH}$ because at a $\mathrm{pH}$ close to 9 , the enzyme has higher performance [57]. Likewise, Table 3 shows that the quadratic effect of temperature on the degree of hydrolysis is also significant ( $\mathrm{p}<0.05$ ), showing that a point of maximum DH can be obtained for a temperature of $50{ }^{\circ} \mathrm{C}$ (see Fig. 1b). These results are in agreement with those described by [58], who, at $\mathrm{pH} 8.5$ and $50{ }^{\circ} \mathrm{C}$, achieved a higher degree of hydrolysis employing Alcalase $2,4 L \AA$ in Catla visceral waste proteins.

\section{Antioxidant content: ABTS and ORAC}

Table 2 shows the results obtained for ABTS and ORAC found for chicken bones under the different processing conditions. These values range from 6531.52 to $8703.26 \mu \mathrm{mol}$ ETrolox/L for the ABTS method and 2779.7 to $11565.04 \mu \mathrm{mol}$ ETrolox/L for ORAC. These antioxidant capacity values are higher than those found for mango [59], orange [60], and beer [61]. 
According to Table 3, none of the factors analyzed significantly affected the ABTS content ( $>>0.05)$. However, the quadratic effect of temperature did significantly affect the ORAC $(p<0.05)$. It was also observed that at higher temperatures and $\mathrm{pH}$ values, the antioxidant content increased according to both the ABTS and ORAC experiments (Fig. 1c and 1d). This behavior has been reported by other scholars [62],[63]. This behavior occurs because through enzymatic hydrolysis, low molecular weight peptides and amino acids are generated; these factors are related to an increase in antioxidant activity, decreasing the chain reactions of free radical formation through the compounds obtained [55-57].

Finally, Equations 5, 6, 7, and 8 show the models obtained by the experimental design for each of the response variables analyzed. In this sense, the coefficients of determination R2 for protein content and degree of hydrolysis were 87.91 and $83.83 \%$, respectively, while for the antioxidant content by ABTS and ORAC, the R2 values were 52.43 and 60.75, respectively.

$$
\begin{array}{r}
\text { Protein }=6.8225-0.165917 * \text { Temperature }-0.516667 * p H+0.0011125 \\
* \text { Temperature }{ }^{2}+0.005 * \text { Temperatura } * p H+0.03125 * p H^{2}
\end{array}
$$

$$
\begin{gathered}
D H=-22.6967+1.20783 * \text { Temperature }+0.548333 * p H-0.0125 * \text { Temperature }^{2} \\
+0.011 * \text { Temperature } * p H+0.01 * p H^{2}(6)
\end{gathered}
$$

$$
\begin{array}{r}
\text { ABTS }=-4689.31+640.308 * \text { Temperature }-1282.07 * p H-7.01902 \\
* \text { Temperature }{ }^{2}+9.61957 * \text { Temperature } * p H+70.9239 * p H^{2}
\end{array}
$$

$$
\begin{gathered}
\text { ORAC }=185915+1630.2 * \text { Temperature }-54839.7 * p H-35.6886 * \text { Temperature }^{2} \\
+242.333 * \text { Temperature } * p H+2670.19 * p H^{2}
\end{gathered}
$$

\section{Optimization of the enzymatic hydrolysis process.}

To optimize the process, a multiple-response optimization methodology was used, maximizing the protein content and degree of hydrolysis; the $\mathrm{pH}$ and temperature conditions were 9 and $50{ }^{\circ} \mathrm{C}$, respectively, and these values were similar to those reported by Novozymes [31].

Table 4 shows the results of the experimental validation of the optimum process conditions, which were tested in triplicate. In general, the values obtained were very close to the values predicted by the model, with the experimental value for protein being 1,830.01 and the degree of hydrolysis being $17.49 \%$.

Table 5 shows the content of nitrogen solubilized through hydrolysis, which was $62.42 \%$ of the initial content in chicken bone meal, for which it has been reported that, through hydrolysis, the protein can be solubilized up to $90 \%$ with Alcalase from treated fleshing meat [67]. It has also been reported that, with this enzyme, a greater number of free amino acids and small peptides is produced than those obtained with the enzyme papain [68].

\section{Glycation process.}

Table 6 shows the results obtained for the antioxidant content by ABTS and ORAC before and after glycation. 
In general, and according to Table 6, the antioxidant content determined by ORAC increased by $6.57 \%$, while the antioxidant content determined by ABTS decreased by $3.73 \%$; this behavior can also be seen in Fig. 2a and $2 \mathrm{~b}$. Likewise, in both cases, the glycation process significantly affected the antioxidant content $(\mathrm{p}<0.05)$, as shown in Fig. $2 \mathrm{a}$ and $2 \mathrm{~b}$. The content of antioxidants decreased according to the ABTS tests, probably because they are thermosensitive; however, it can be said that after glycation, antioxidants can undergo further hydrogen transfer (HAT), which is the reason that the ORAC is higher [69].

This result is related to the fact that through the glycation of the amino groups of the proteins or peptides present in the matrix and a reducing sugar, in this case, lactose, antioxidant compounds can be generated; these antioxidant compounds have the capacity to eliminate free radicals. Antioxidants can delay oxidative deterioration in different matrices, which is why it has been suggested that compounds obtained through glycation could be used as functional ingredients in the food industry [70].

\section{HMF and Furfural}

Through the glycation process, compounds known as melanoidins are formed; these compounds have been reported to reduce peroxyl radicals [71]. In turn, this reaction also detects the formation of HMF and furfural, which are indicators of advanced glycation end products (AGE) of the intermediate stages of the Maillard reaction [45]. Both compounds have been reported to have toxic and carcinogenic effects [72]. The EFSA has already established an ADI (acceptable daily intake) value of $0.5 \mathrm{mg} / \mathrm{kg}$ bw/d for furfural [73]. Additionally, the Scientific Panel on Food Additives, Flavorings, Processing Aids and Food Contact Materials estimated a dietary intake of HMF of $1.6 \mathrm{mg} /$ person per day based on a modified Theoretical Maximum Daily Added Intake (mTAMDI) approach [74]. According to the European Union Regulation of honey, maximum HMF limits have been established, and these limits vary according to the type of honey; in general, a maximum value of $40 \mathrm{mg} / \mathrm{kg}$ is accepted, except for honey for industrial use. A maximum of $80 \mathrm{mg} / \mathrm{kg}$ is accepted for honey of tropical origins [75].

Table 2 shows the HMF and furfural contents of the glycated samples, which ranged from 0.05 to $0.22 \mathrm{mg} \mathrm{HMF} / \mathrm{L}$ and 0 to $0.26 \mathrm{mg}$ furfural/L. The HMF values are lower than those reported in previous studies [76] of beer and balsamic vinegar [77]. The measured furfural contents are lower than those reported to be in fruit juices [76] and [78] in Marsala wine. It should be noted that the $\mathrm{HMF}$ and furfural contents are low, so glycation of $\mathrm{CBH}$ at $60^{\circ} \mathrm{C}$ for 24 hours does not lead to a significant formation of the analyzed thermal damage indicator compounds because the Maillard reaction is promoted when food systems containing reducing sugars and amino acids are treated at high temperatures $\left(>120^{\circ} \mathrm{C}\right)[79]$.

The furfural content presented in Table 2 is low because lactose mainly degrades to form HMF [80], because this disaccharide is composed of two hexoses, which generally promotes the formation of $\mathrm{HMF}$; in contrast, furfural is derived from pentoses [81].

Fig. 3a shows that the highest HMF content was observed after treatments 1 and 2, which were significantly different from the other treatments $(\mathrm{p}<0.05)$; these results corresponded to temperature conditions of $50{ }^{\circ} \mathrm{C}$ and $\mathrm{pH} 8$ and 9, respectively. Significant differences in the furfural content (Fig. $3 \mathrm{~b}$ ) were found mainly for treatment 4 , which involved conditions of $50{ }^{\circ} \mathrm{C}$ at $\mathrm{pH} 7$.

\section{Conclusion}


In general, it can be concluded that chicken bones are a raw material that can be used in enzymatic hydrolysis to obtain bioactive compounds such as antioxidants. In addition, by means of the factorial experimental design, it was possible to establish the best operating conditions of enzymatic hydrolysis to maximize the protein content and the degree of hydrolysis; it was evidenced that glycation has a significant effect on the content of antioxidant compounds and does not lead to the formation of advanced glycation end products (AGE) such as HMF and furfural. Finally, the compounds obtained here could be used in the development of new food matrices, thus serving as an alternative to the disposal of the byproducts generated by the chicken industry.

\section{Acknowledgments}

The authors would like to thank the BIOALI (Food Biotechnology Research Group), NUTEC (Food and Nutrition Technology Research Group) and GEMCA (Drug, Cosmetic and Food Stability Group), Faculty of Pharmaceutical and Food Sciences, Universidad de Antioquia, for their support in the development of this project.

\section{Disclosure statement}

The authors declare no conflict of interest

\section{Declarations}

Funding: The authors did not receive support from any organization for the submitted work.

Availability of data and material: The datasets generated during and/or analysed during the current study are available from the corresponding author on reasonable request.

Code availability: The data were analyzed with Statgraphics Centurion XVI version 16.1.03 software.

Author's contributions: All authors had readen and agree with the published version of the manuscript. Conceptualization, methodology, formal analysis, experimental research, writing: preparation of the original draft, Luisa Londoño, Sara Franco and Sandra Restrepo; accompaniment of the experimental phase and resources, Lina Suárez, Fáver Gómez; writing: proofreading and editing, Óscar Vega, Pedro Valencia; visualization, Helena Núñez, Ricardo Simpson.

\section{References}

1. Latin American Chicken Institute.: Global chicken meat production: 2000-2018. https://ilpala.org/producion-mundial-de-carne-de-pollo-2000-2018/\#horizontalTab-5205 (2018). Accessed 04 February 2021

2. FAO.: World agriculture: Towards 2015/2030: An FAO perspective. Earthscan, London (2003)

3. Martínez-Alvarez, O., Chamorro, S., \& Brenes, A.: Protein hydrolysates from animal processing by-products as a source of bioactive molecules with interest in animal feeding: A review. Food Research International. (2015). https://doi.org/ 10.1016/j.foodres.2015.04.005

4. Nascimento, C.D., Filho, R.A., Artur, A.G., \& Costa, M.: Application of poultry processing industry waste: a strategy for vegetation growth in degraded soil. Waste management. (2015). https://doi.org/10.1016/j.wasman.2014.11.001 
401

402

403

404

405

406

407

408

409

410

411

412

413

5. Ferreira, A., Kunh, S.S., Cremonez, P.A., Dieter, J., Teleken, J.G., Sampaio, S.C., \& Kunh, P.D.: Brazilian poultry activity waste: Destinations and energetic potential. Renewable \& Sustainable Energy Reviews. (2018). https://doi.org/10.1016/j.rser.2017.08.078

6. FIRA.: Agri-food panorama. Chicken meat 2019. https://www.inforural.com.mx/wpcontent/uploads/2019/09/Panorama-Agroalimentario-Carne-de-pollo-2019.pdf (2019). Accessed 04 February 2021

7. FENAVI:: Report FENAVIQUÍN: Economic Studies Program -Fenavi-Fonav. https://www.solla.com/sites/default/files/productos/secciones/adjuntos/Fenaviquin_ed-295-oct-152019.pdf (2019). Accessed 04 February 2021

8. Özünlü, O., Ergezer, H., \& Gökçe, R.: Improving physicochemical, antioxidative and sensory quality of raw chicken meat by using acorn extracts. Lwt - Food Science and Technology (2018). https://doi.org/10.1016/j.lwt.2018.09.007

9. Dalle Zotte A, Ricci R, Cullere M, Serva L, Tenti S, Marchesini G.: Research Note: Effect of chicken genotype and white striping-wooden breast condition on breast meat proximate composition and amino acid profile. Poultry Science (2020). https://doi.org/10.1016/j.psj.2019.10.066

10. Kim, Hee-Jin \& Kim, Hye-Jin \& Jeon, JinJoo \& Nam, Ki-Chang \& Shim, Kwan-Seob \& Jung, Jong-Hyun \& Kim, Kyong \& Choi, Yangil \& Kim, Sang-Ho \& Jang, Aera.: Comparison of the quality characteristics of chicken breast meat from conventional and animal welfare farms under refrigerated storage. Poultry Science (2020). https://doi.org/10.1016/j.psj.2019.12.009

11. Kralik, G., Z. Kralik, M. Grčević, and D. Hanžek.: Quality of Chicken Meat. In: Animal Husbandry and Nutrition; Yücel, B.; Taşkin, T., IntechOpen (2018). https://doi.org/10.5772/intechopen.72865

12. Mehdizadeh, T. and A. M. Langroodi.: Chitosan coatings incorporated with propolis extract and Zataria multiflora Boiss oil for active packaging of chicken breast meat. International journal of biological macromolecules (2019). https://doi.org/10.1016/j.ijbiomac.2019.08.267

13. Brandelli, A., Sala, L., \& Juliano, S.: Microbial enzymes for bioconversion of poultry waste into added-value products. Food Research International (2015). https://doi.org/10.1016/j.foodres.2015.01.015

14. Ding, Guitao \& Li, Songlin \& Wang, An \& Chen, Naisong.: Effect of chicken haemoglobin powder on growth, feed utilization, immunity and haematological index of largemouth bass (Micropterus salmoides). Aquaculture and Fisheries (2019). https://doi.org/10.1016/j.aaf.2019.04.003

15. Xia, Y., Wang, D. K., Kong, Y., Ungerfeld, E. M., Seviour, R., \& Massé, D. I.: Anaerobic digestibility of beef hooves with swine manure or slaughterhouse sludge. Waste Management (2015). https://doi.org/10.1016/j.wasman.2014.12.017

16. AlSharifi, M., \& Znad, H.: Development of a lithium based chicken bone (Li-Cb) composite as an efficient catalyst for biodiesel production. Renewable Energy (2019). https://doi.org/10.1016/j.renene.2019.01.052 
414 17. Wang, J. Z., Dong, X. B., Yue, J. Y., Zhang, C. H., Jia, W., \& Li, X.: Preparation of Substrate 415 for Flavorant from Chicken Bone Residue with Hot-Pressure Process. Journal of Food Science 416 (2016). https://doi.org/10.1111/1750-3841.13211

417 18. Lasekan, A., Abu, F., \& Hashim, D.: Potential of chicken by-products as sources of useful 418 biological resources. Waste Management (2013). https://doi.org/10.1016/j.wasman.2012.08.001

419 19. Dong, Z. Y., Li, M. Y., Tian, G., Zhang, T. H., Ren, H., \& Quek, S. Y.: Effects of ultrasonic 420 pretreatment on the structure and functionality of chicken bone protein prepared by enzymatic 421 method. Food Chemistry (2019). https://doi.org/10.1016/j.foodchem.2019.125103

422 20. Karami, Z., Peighambardoust, S. H., Hesari, J., Akbari-Adergani, B., \& Andreu, D.: 423 Antioxidant, anticancer and ACE-inhibitory activities of bioactive peptides from wheat germ protein 424 hydrolysates. Food Bioscience (2019). https://doi.org/10.1016/j.fbio.2019.100450

425 21. Zheng, Z., Li, J., Li, J., Sun, H., \& Liu, Y.: Physicochemical and antioxidative characteristics 426 https://doi.org/10.1016/j.foodhyd.2019.105222

22. Khiari, Z., Ndagijimana, M., \& Betti, M.: Low molecular weight bioactive peptides derived from the enzymatic hydrolysis of collagen after isoelectric solubilization/precipitation process of turkey by-products. Poultry Science (2014). https://doi.org/10.3382/ps.2014-03953

23. Neves, A. C., Harnedy, P. A., O’Keeffe, M. B., Alashi, M. A., Aluko, R. E., \& FitzGerald, R. J.: Peptide identification in a salmon gelatin hydrolysate with antihypertensive, dipeptidyl peptidase IV inhibitory and antioxidant activities. Food Research International (2017). https://doi.org/10.1016/j.foodres.2017.06.065

24. Zheng, Z., Si, D., Ahmad, B., Li, Z., \& Zhang, R.: A novel antioxidative peptide derived from chicken blood corpuscle hydrolysate. Food Research International (2018). https://doi.org/10.1016/j.foodres.2017.12.078

25. Udenigwe, C. C., Udechukwu, M. C., Yiridoe, C., Gibson, A., \& Gong, M.: Antioxidant mechanism of potato protein hydrolysates against in vitro oxidation of reduced glutathione. Journal of Functional Foods (2016). https://doi.org/10.1016/j.jff.2015.11.004

26. Sun, W., Zhao, M., Cui, C., Zhao, Q., \& Yang, B.: Effect of Maillard reaction products derived from the hydrolysate of mechanically deboned chicken residue on the antioxidant, textural and sensory properties of Cantonese sausages. Meat Science (2010). https://doi.org/10.1016/j.meatsci.2010.04.014

27. Siewe, F. B., Kudre, T. G., Bettadaiah, B. K., \& Narayan, B.: Effects of ultrasound-assisted heating on aroma profile, peptide structure, peptide molecular weight, antioxidant activities and sensory characteristics of natural fish flavouring. Ultrasonics Sonochemistry (2020). https://doi.org/10.1016/j.ultsonch.2020.105055

28. Liu, Q., Kong, B., Han, J., Sun, C., \& Li, P.: Structure and antioxidant activity of whey protein isolate conjugated with glucose via the Maillard reaction under dry-heating conditions. Food Structure (2014). https://doi.org/10.1016/j.foostr.2013.11.004

29. Nooshkam, M., \& Madadlou, A.: Maillard conjugation of lactulose with potentially bioactive peptides. Food Chemistry (2016). https://doi.org/10.1016/j.foodchem.2015.07.094 
30. Han, W., Liu, Y., Xu, X., Huang, J., He, H., Chen, L., Hou, P.: Bioethanol production from waste hamburger by enzymatic hydrolysis and fermentation. Journal of Cleaner Production (2020). https://doi.org/10.1016/j.jclepro.2020.121658

31. Novozymes.: Alcalase Food Grade. Product sheet. http://www.ebiosis.co.kr/Novozymes\%20Product\%20Sheet/Alcalase\%202.4L.pdf (2002). Accessed 04 February 2021

32. Nie, X., Zhao, L., Regenstein, J. M., Xu, D., \& Meng, X.: Antioxidant capacity of Maillard reaction products' fractions with different molecular weight distribution from chicken bone hydrolysate - galactose system. International Journal of Food Science and Technology (2017). https://doi.org/10.1111/ijfs.13445

33. AOAC: Official method of Analysis. (18th edn.). Gaithersburg, MD, USA (2005)

34. Valencia, P., Pinto, M., \& Almonacid, S.: Identification of the key mechanisms involved in the hydrolysis of fish protein by Alcalase. Process Biochemistry (2014). https://doi.org/10.1016/j.procbio.2013.11.012

35. Gbogouri, G., Linder, M., Fanni, J., \& Parmentier, M.: Influence of hydrolysis degree on the functional properties of salmon byproducts hydrolysates. Journal of Food Science (2004). https://doi.org/10.1111/j.1365-2621.2004.tb09909.x

36. Beaubier, S., Framboisier, X., Ioannou, I., Galet, O., \& Kapel, R.: Simultaneous quantification of the degree of hydrolysis, protein conversion rate and mean molar weight of peptides released in the course of enzymatic proteolysis. Journal of Chromatography B (2019). https://doi.org/10.1016/j.jchromb.2018.12.005

37. Samaranayaka, A. G. P.: Pacific hake (merluccius productus) fish protein hydrolysates with antioxidative properties. https://open.library.ubc.ca/cIRcle/collections/ubctheses/24/items/1.0069207 (2010). Accessed 04 February 2021

38. U. Khulal, S. Ghnimi, N. Stevanovic, A. Rajkovic, and T. C. Velickovic, "Aggregability and digestibility study of fruit juice fortified camel milk powder proteins," Lwt, vol. 152, p. 112250, (2021). https://doi.org/10.1016/j.lwt.2021.112250.

39. X. Xu, Y. Qiao, B. Shi, and V. P. Dia, "Alcalase and bromelain hydrolysis affected physicochemical and functional properties and biological activities of legume proteins," Food Struct., vol. 27, no. January, p. 100178, (2021). https://doi.org/10.1016/j.foostr.2021.100178.

40. Li, Y., Lu, F., Luo, C., Chen, Z., Mao, J., Shoemaker, C., \& Zhong, F.: Functional properties of the Maillard reaction products of rice protein with sugar. Food Chemistry (2009). https://doi.org/10.1016/j.foodchem.2009.03.078

41. Brescia, P. J.: Determination of Antioxidant potential using an Oxygen Radical Absorbance Capacity (ORAC) Assay with Synergy TM H4. BioTek Application. https://www.biotek.com/assets/tech_resources/ORAC_App_Note.pdf (2012). Accessed 04 February 2021

42. Duarte-Correa, Y., Díaz-Osorio, A., Osorio-Arias, J., Sobral, P. J. A., \& Vega-Castro, O.: Development of fortified low-fat potato chips through Vacuum Impregnation and Microwave 
Vacuum Drying. Innovative Food Science and Emerging Technologies (2020). https://doi.org/10.1016/j.ifset.2020.102437

43. León Méndez, G., Osorio Fortich, M. del R., Torrenegra, M. E., \& González, J. G.: Extraction, characterization and antioxidant activity of the essential oil of plectranthus amboinicus L. Revista Cubana de Farmacia. 49(4), 708-718 (2015).

44. Contreras-Calderón, J., Guerra-Hernández, E., \& García-Villanova, B.: Indicators of nonenzymatic browning in the evaluation of heat damage of ingredient proteins used in manufactured infant formulas. European Food Research and Technology (2008). https://doi.org/10.1007/s00217007-0700-2

45. Gómez-Narváez, F., Contreras-Calderón, J., \& Pérez-Martínez, L.: Usefulness of some Maillard reaction indicators for monitoring the heat damage of whey powder under conditions applicable to spray drying. International Dairy Journal (2019). https://doi.org/10.1016/j.idairyj.2019.104553

46. Spanish Foundation for the Development of Animal Nutrition. FEDNA.: Meat meal, 50/14/26. http://www.fundacionfedna.org/ingredientes_para_piensos/harina-de-carne-501426. Accessed 04 February 2021

47. ChileMink, Ingredients for animal consumption.: Technical data sheet meat and bone meal. https://irpcdn.multiscreensite.com/9a7951af/files/uploaded/Ficha\%20Tecnica\%20Harina\%20Rev3\%20sept\% 2015\%202020.pdf (2018). Accessed 04 February 2021

48. RAMGRAS S.A.C.I.A. ).: Meat and bone meal specifications 40/45\% proteins. http://ramgras.com.ar/es-ficha-tecnica-harina-de-carne-y-huesos.pdf. Accessed 04 February 2021

49. Protidos.: Raw materials for animal nutrition. http://dianuro.com/FICHASPROTIDOS.pdf (2017). Accessed 04 February 2021

50. Hamzeh, A., Wongngam, W., Kiatsongchai, R., \& Yongsawatdigul, J.: Cellular and chemical antioxidant activities of chicken blood hydrolysates as affected by in vitro gastrointestinal digestion. Poultry Science (2019). https://doi.org/10.3382/ps/pez283

51. dos Santos Aguilar, J. G., de Souza, A. K. S., \& de Castro, R. J. S.: Enzymatic Hydrolysis of Chicken Viscera to Obtain Added-Value Protein Hydrolysates with Antioxidant and Antihypertensive Properties. International Journal of Peptide Research and Therapeutics, (2020). https://doi.org/10.1007/s10989-019-09879-3

52. Dhakal, D., Koomsap, P., Lamichhane, A., Sadiq, M. B., \& Anal, A. K.: Optimization of collagen extraction from chicken feet by papain hydrolysis and synthesis of chicken feet collagen based biopolymeric fibres. Food Bioscience (2018). https://doi.org/10.1016/j.fbio.2018.03.003

53. Bao, Z. jie, Zhao, Y., Wang, X. ying, \& Chi, Y. J.: Effects of degree of hydrolysis (DH) on the functional properties of egg yolk hydrolysate with alcalase. Journal of Food Science and Technology (2017). https://doi.org/10.1007/s13197-017-2504-0

54. Cumby, N., Zhong, Y., Naczk, M., \& Shahidi,: Antioxidant activity and water-holding capacity of canola protein hydrolysates. Food Chemistry (2008). https://doi.org/10.1016/j.foodchem.2007.12.039 
55. Ahn, C. B., Jeon, Y. J., Kim, Y. T., \& Je, J. Y.: Angiotensin i converting enzyme (ACE) inhibitory peptides from salmon byproduct protein hydrolysate by Alcalase hydrolysis. Process Biochemistry (2012). https://doi.org/10.1016/j.procbio.2012.08.019

56. Vv, R., Ghaly, A., Brooks, M., \& Budge, S.: Extraction of Proteins from Mackerel Fish Processing Waste Using Alcalase Enzyme. Journal of Bioprocessing \& Biotechniques (2013). https://doi.org/10.4172/2155-9821.1000130

57. Yu, L., Sun, J., Liu, S., Bi, J., Zhang, C., \& Yang, Q.: Ultrasonic-assisted enzymolysis to improve the antioxidant activities of peanut (Arachin conarachin L.) antioxidant hydrolysate. International Journal of Molecular Sciences (2012). https://doi.org/10.3390/ijms13079051

58. Bhaskar, N., Benila, T., Radha, C., \& Lalitha, R. G.: Optimization of enzymatic hydrolysis of visceral waste proteins of Catla (Catla catla) for preparing protein hydrolysate using a commercial protease. Bioresource Technology (2008). https://doi.org/10.1016/j.biortech.2006.12.015

59. Londoño, M. B. Z., Chaparro, D., Rojano, B. A., Arbelaez, A. F. A., Betancur, L. F. R., \& Celis, M. E. M.: Effect of storage time on physicochemical, sensorial, and antioxidant characteristics, and composition of mango (cv. Azúcar) juice. Emirates Journal of Food and Agriculture (2017). https://doi.org/10.9755/ejfa.2016-09-1256

60. Seeram, N. P., Aviram, M., Zhang, Y., Henning, S. M., Feng, L., Dreher, M., \& Heber, D.: Comparison of antioxidant potency of commonly consumed polyphenol-rich beverages in the United States. Journal of Agricultural and Food Chemistry (2008). https://doi.org/10.1021/jf073035s

61. Wannenmacher, J., Cotterchio, C., Schlumberger, M., Reuber, V., Gastl, M., \& Becker, T.: Technological influence on sensory stability and antioxidant activity of beers measured by ORAC and FRAP. Journal of the Science of Food and Agriculture (2019). https://doi.org/10.1002/jsfa.9979

62. Shu, G., Zhang, B., Zhang, Q., Wan, H., \& Li, H.: Effect of Temperature, pH, Enzyme to Substrate Ratio, Substrate Concentration and Time on the Antioxidative Activity of Hydrolysates from Goat Milk Casein by Alcalase. Acta Universitatis Cibiniensis. Series E: Food Technology (2016). https://doi.org/10.1515/aucft-2016-0013

63. Dey, S. S., \& Dora, K. C.: Antioxidative activity of protein hydrolysate produced by alcalase hydrolysis from shrimp waste (Penaeus monodon and Penaeus indicus). Journal of Food Science and Technology (2014). https://doi.org/10.1007/s13197-011-0512-z

64. Chakka, A. K., Elias, M., Jini, R., Sakhare, P. Z., \& Bhaskar, N.: In-vitro antioxidant and antibacterial properties of fermentatively and enzymatically prepared chicken liver protein hydrolysates. Journal of Food Science and Technology (2015). https://doi.org/10.1007/s13197-015$1920-2$

65. Wu, H. C., Chen, H. M., \& Shiau, C. Y. (2003). Free amino acids and peptides as related to antioxidant properties in protein hydrolysates of mackerel (Scomber austriasicus). Food Research International (2003). https://doi.org/10.1016/S0963-9969(03)00104-2

66. Xiong, G. Y., Chen, X., Zhang, X. X., Miao, Y., Zou, Y., Wang, D. Y., \& Xu, W. M.: Process optimization and the relationship between the reaction degree and the antioxidant activity of Maillard reaction products of chicken liver protein hydrolysates. Poultry Science (2020). https://doi.org/10.1016/j.psj.2020.03.027 
574 67. Zhang, Y., Olsen, K., Grossi, A., \& Otte, J., Effect of pretreatment on enzymatic hydrolysis 575 of bovine collagen and formation of ACE-inhibitory peptides. Food Chemistry (2013). 576 https://doi.org/10.1016/j.foodchem.2013.05.058

577 68. Anzani, C., Prandi, B., Tedeschi, T., Baldinelli, C., Sorlini, G., Wierenga, P. A., ... Sforza, 578 S.: Degradation of Collagen Increases Nitrogen Solubilisation During Enzymatic Hydrolysis of 579 Fleshing Meat. Waste and Biomass Valorization (2018). https://doi.org/10.1007/s12649-017-9866-4

580 69. Yim, H. S., Chye, F. Y., Rao, V., Low, J. Y., Matanjun, P., How, S. E., \& Ho, C. W.: 581 Optimization of extraction time and temperature on antioxidant activity of Schizophyllum commune 582 aqueous extract using response surface methodology. Journal of Food Science and Technology 583 (2013). https://doi.org/10.1007/s13197-011-0349-5

584 70. Sun, Y., Hayakawa, S., Ogawa, M., \& Izumori, K.: Evaluation of the site specific protein 585 glycation and antioxidant capacity of rare sugar-protein/peptide conjugates. Journal of Agricultural 586 and Food Chemistry (2005). https://doi.org/10.1021/jf051565n

587 71. Gómez-Ruiz, J. Á., Ames, J. M., \& Leake, D. S.: Antioxidant activity and protective effects 588 of green and dark coffee components against human low density lipoprotein oxidation. European 589 Food Research and Technology (2008). https://doi.org/10.1007/s00217-007-0815-5

590 72. Gülcan, Ü., Candal Uslu, C., Mutlu, C., Arslan-Tontul, S., \& Erbaş, M.: Impact of inert and 591 inhibitor baking atmosphere on HMF and acrylamide formation in bread. Food Chemistry (2020). 592 https://doi.org/10.1016/j.foodchem.2020.127434

593 73. Arribas-Lorenzo, G., \& Morales, F. J.: Estimation of dietary intake of 5594 hydroxymethylfurfural and related substances from coffee to Spanish population. Food and Chemical 595 Toxicology (2010). https://doi.org/10.1016/j.fct.2009.11.046

596 74. EFSA. Opinion of the Scientific Panel on food additives, flavourings, processing aids and 597 materials in contact with food (AFC) related to Flavouring Group Evaluation 13 (FGE.13); Furfuryl 598 and furan derivatives with and without additional side-chain substituents. EFSA Journal (2005). 599 https://doi.org/10.2903/j.efsa.2005.215

600 75. Council directive. Official Journal of the European Communities. https://eur601 lex.europa.eu/legal-content/EN/TXT/PDF/?uri=CELEX:32001L0110\&from=ES (2002). Accessed $602 \quad 04$ February 2021

603 76. Yuan, J. P., \& Chen, F.: Separation and Identification of Furanic Compounds in Fruit Juices 604 and Drinks by High-Performance Liquid Chromatography Photodiode Array Detection. Journal of 605 Agricultural and Food Chemistry (1998). https://doi.org/10.1021/jf970894f

606 77. Theobald, A., Müller, A., \& Anklam, E.: Determination of 5-Hydroxymethylfurfural in 607 Vinegar Samples by HPLC. Journal of Agricultural and Food Chemistry (1998). 608 https://doi.org/10.1021/jf970912t

609 78. Ortu, E., \& Caboni, P.: Levels of 5-hydroxymethylfurfural, furfural, 2-furoic acid in sapa 610 syrup, Marsala wine and bakery products. International Journal of Food Properties (2018). 611 https://doi.org/10.1080/10942912.2017.1373668

612 79. Purlis, E., \& Salvadori, V. O.: Modelling the browning of bread during baking. Food 613 Research International (2009). https://doi.org/10.1016/j.foodres.2009.03.007 
614 80. Eskin, N. A. M., Ho, C. T., \& Shahidi, F.: Browning Reactions in Foods. Biochemistry of 615 Foods (2012). https://doi.org/10.1016/B978-0-08-091809-9.00006-6

616 81. Peleteiro, S., Garrote, G., Santos, V., \& Parajó, J. C.: Conversion of hexoses and pentoses 617 into furans in an ionic liquid. Afinidad. 71. 202-206 (2014) 


\section{List of figures}

Fig. 1 Surface response showing the effect of temperature and $\mathrm{pH}$ on a) protein content, b) degree of hydrolysis (DH), c) antioxidant content by ABTS and d) ORAC.

Fig. 2 Graph of average antioxidant content by a) ABTS and b) ORAC.

Fig. 3 Graph of average contents of a) HMF and b) furfural in the glycated samples. 
Fig. 1 Surface response showing the effect of temperature and $\mathrm{pH}$ on a) protein content, b) degree of hydrolysis (DH), c) antioxidant content by ABTS and d) ORAC.
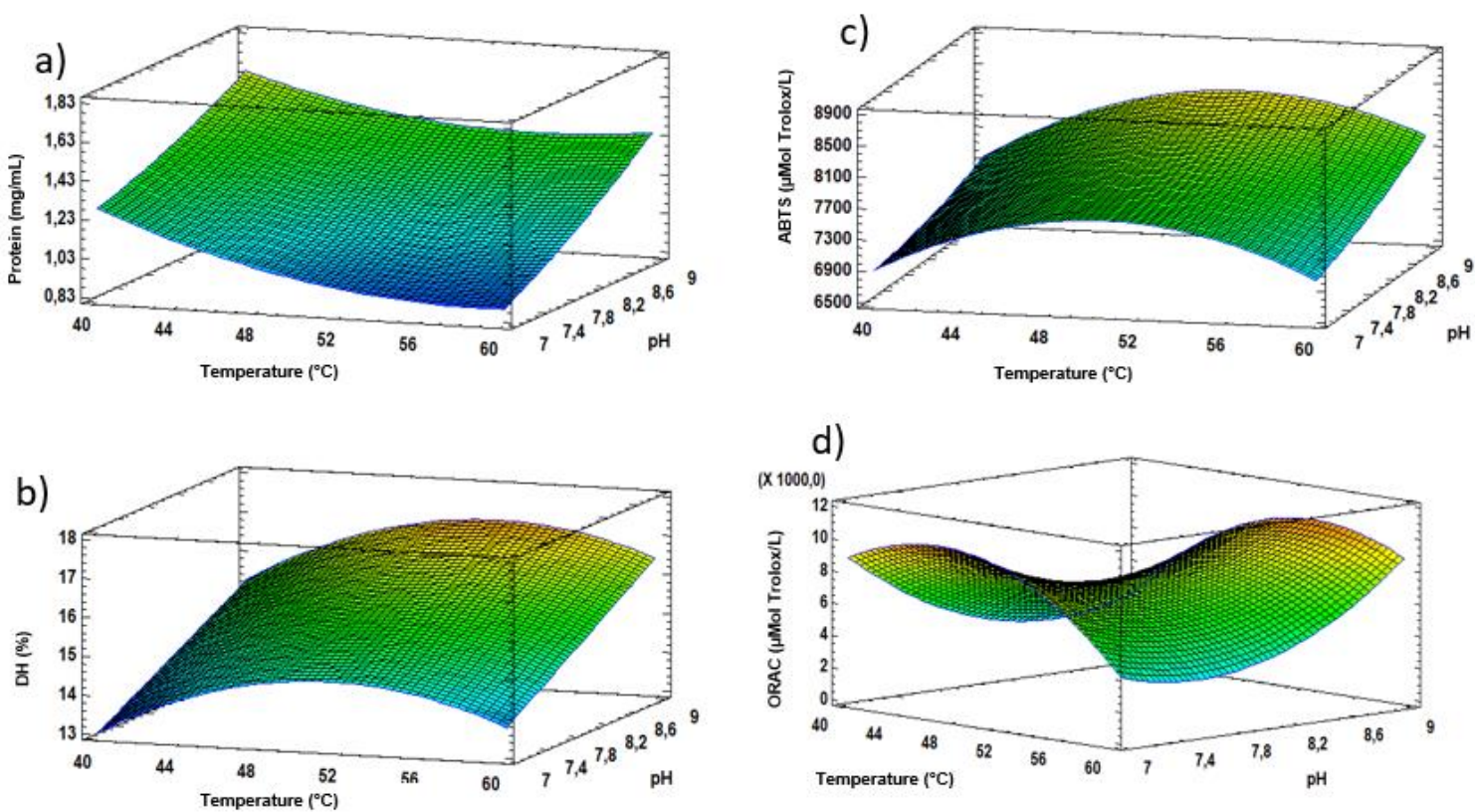
Fig. 2 Graph of average antioxidant content by a) ABTS and b) ORAC.
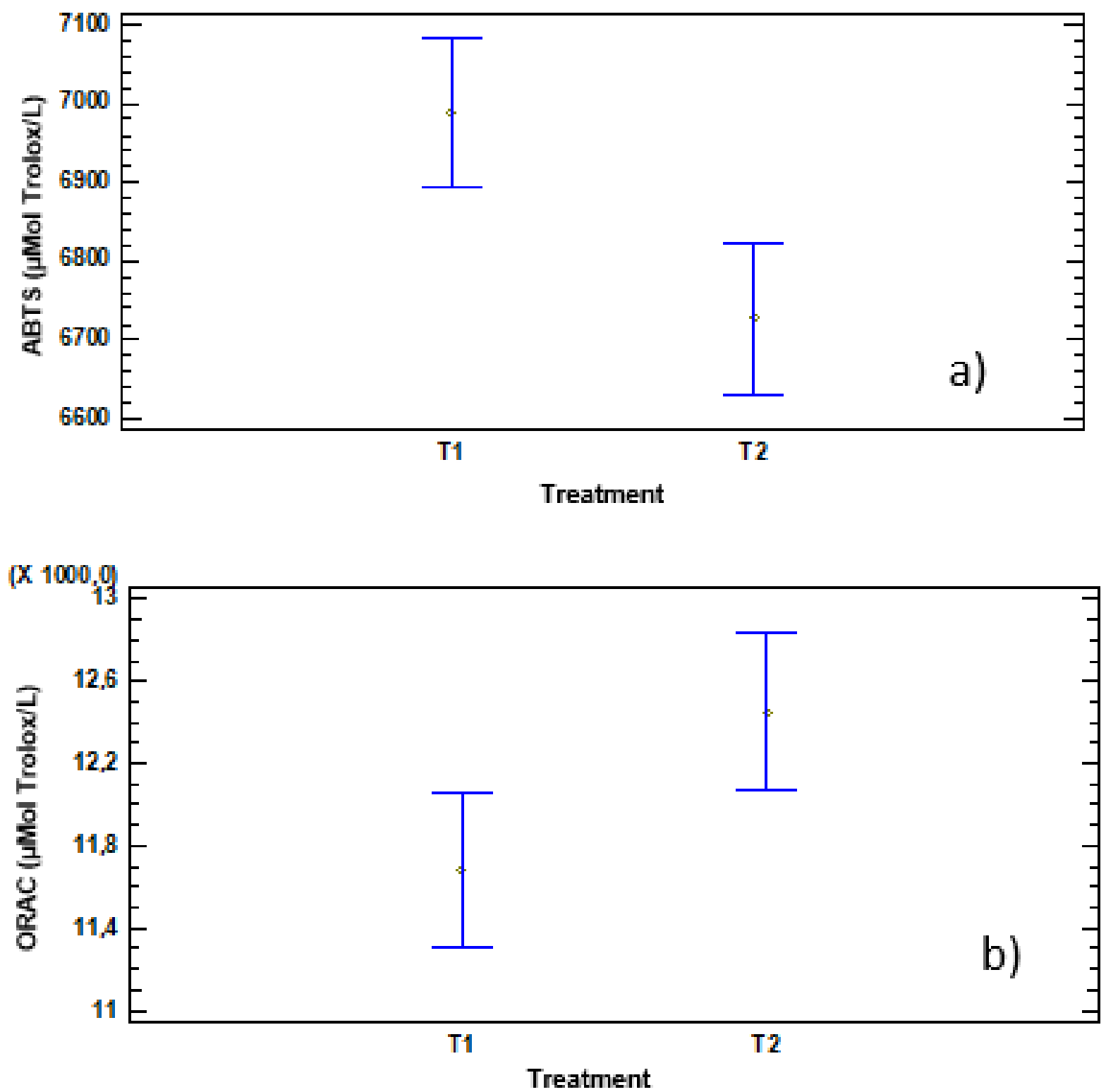

*T1: Hydrolyzed, T2: Glycated 
Fig. 3 Graph of average contents of a) HMF and b) furfural in the glycated samples.
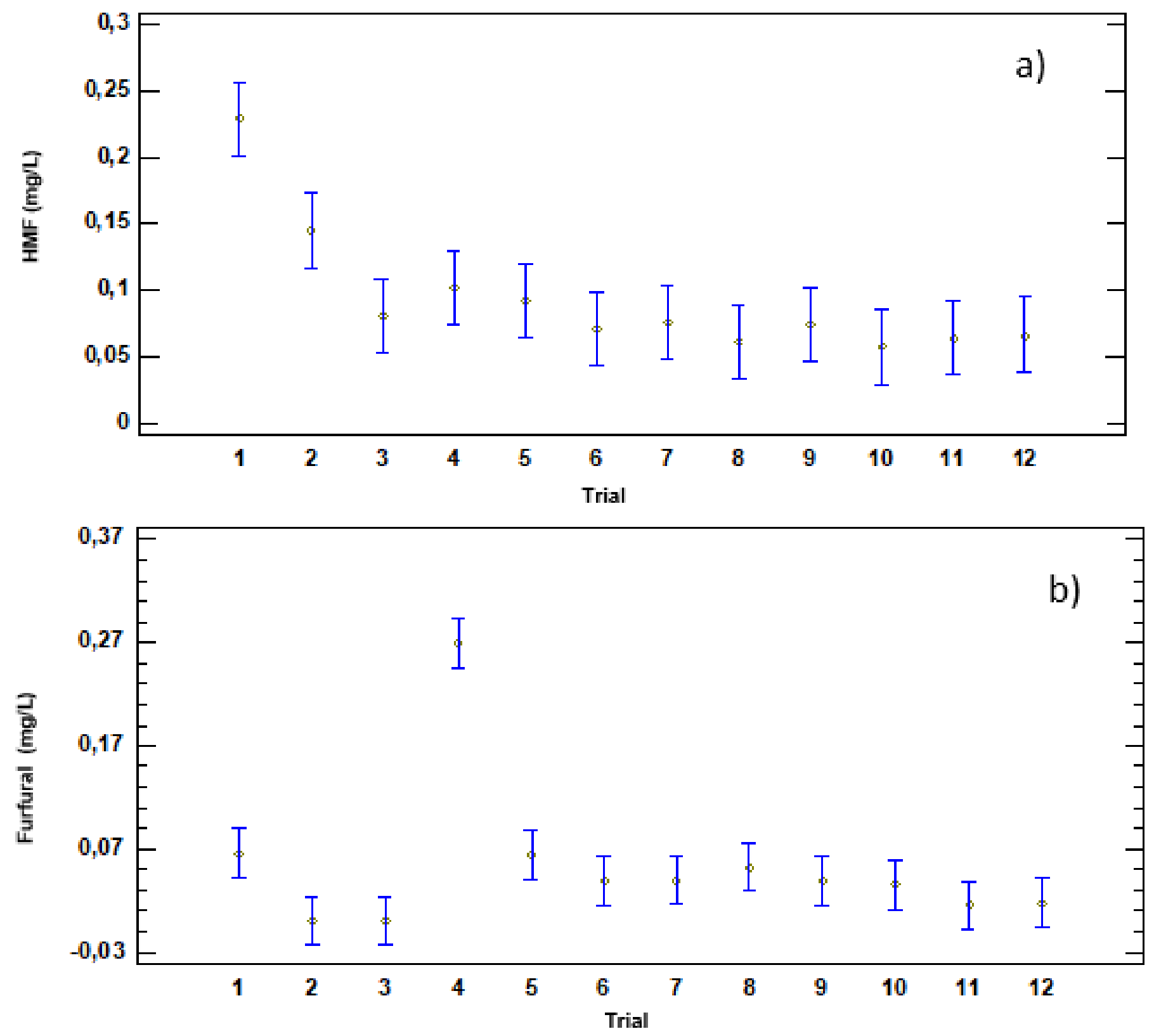


\section{List of tables}

Table 1. Proximal characterization of chicken bone meal.

Table 2. Experimental data for the different combinations of temperature and $\mathrm{pH}$ for the enzymatic hydrolysis of chicken bones.

Table 3. $p$ values of the response variables in relation to the factors and their interactions.

Table 4. Experimental validation.

Table 5. Nitrogen content in the chicken bone meal and hydrolysate phases.

Table 6. Antioxidant content of the hydrolysate before and after glycation. 
Table 1. Proximal characterization of chicken bone meal.

\begin{tabular}{lc}
\hline \multicolumn{1}{c}{ Component } & Percentage (\%) \\
\hline Protein $(\mathrm{N} \times 6,25)$ & $47.17 \pm 3.93$ \\
Ash & $24.61 \pm 0.76$ \\
Moisture & $7.2 \pm 0.05$ \\
Total fat & $19.04 \pm 0.17$ \\
Carbohydrates & $2 \pm 3.16$ \\
\hline
\end{tabular}


Table 2. Experimental data for the different combinations of temperature and $\mathrm{pH}$ for the enzymatic hydrolysis of chicken bones.

\begin{tabular}{|c|c|c|c|c|c|c|c|c|}
\hline \multirow{2}{*}{ Trial $\mathbf{N}^{\circ}$} & \multicolumn{2}{|l|}{ Factor } & \multicolumn{4}{|c|}{ Response variable } & \multirow{2}{*}{$\begin{array}{c}\text { HMF } \\
\text { (mg/ } \\
\text { L) }\end{array}$} & \multirow[b]{2}{*}{$\begin{array}{c}\text { Furfural } \\
\text { (mg/L) }\end{array}$} \\
\hline & $\begin{array}{c}\text { Temperature } \\
\left({ }^{\circ} \mathrm{C}\right)\end{array}$ & $\mathrm{pH}$ & $\begin{array}{c}\text { ORAC } \\
(\mu \mathrm{Mol} \text { ETrolox/L) }\end{array}$ & $\begin{array}{c}\text { ABTS } \\
(\mu \mathrm{Mol} \text { ETrolox } / \mathrm{L})\end{array}$ & $\begin{array}{l}\mathrm{DH} \\
(\%)\end{array}$ & $\begin{array}{l}\text { Protein } \\
(\mathrm{mg} / \mathrm{mL})\end{array}$ & & \\
\hline 1 & 50 & 8 & 9888.55 & 7968.48 & 15.83 & 1.04 & 0.23 & 0.17 \\
\hline 2 & 50 & 9 & 11565.04 & 8233.7 & 17.98 & 1.38 & 0.14 & ND \\
\hline 3 & 40 & 7 & 9616.69 & 6531.52 & 13.59 & 1.18 & 0.08 & ND \\
\hline 4 & 50 & 7 & 10779.09 & 8077.17 & 13.85 & 1.12 & 0.10 & 0.27 \\
\hline 5 & 50 & 8 & 7707.29 & 8703.26 & 15.27 & 1.16 & 0.09 & 0.06 \\
\hline 6 & 60 & 8 & 6623.65 & 7256.52 & 15.47 & 1.13 & 0.07 & 0.04 \\
\hline 7 & 60 & 9 & 6864.6 & 8041.3 & 15.86 & 1.51 & 0.08 & 0.04 \\
\hline 8 & 50 & 8 & 5768.67 & 7516.3 & 16.4 & 1.21 & 0.06 & 0.05 \\
\hline 9 & 60 & 7 & 4008.25 & 6926.09 & 13.93 & 0.84 & 0.07 & 0.04 \\
\hline 10 & 50 & 8 & 3499.42 & 7096.74 & 15.92 & 1.2 & 0.06 & 0.04 \\
\hline 11 & 40 & 9 & 2779.7 & 7261.96 & 15.08 & 1.65 & 0.06 & 0.02 \\
\hline 12 & 40 & 8 & 3242.38 & 7508.7 & 13.84 & 1.53 & 0.07 & 0.02 \\
\hline
\end{tabular}


Table 3. $p$ values of the response variables in relation to the factors and their interactions.

\begin{tabular}{ccccc}
\hline $\begin{array}{c}\text { Factors and } \\
\text { interactions }\end{array}$ & Protein & $\begin{array}{c}\text { Degree of } \\
\text { hydrolysis }\end{array}$ & ABTS & ORAC \\
\hline $\mathbf{T}$ & $0.0161^{*}$ & 0.1625 & 0.5419 & - \\
$\mathbf{p H}$ & 0.0019 & 0.0047 & 0.2098 & - \\
$T^{2}$ & 0.1449 & 0.0275 & 0.0965 & 0.0335 \\
$\mathbf{p H} \times T$ & 0.392 & 0.7656 & 0.7522 & 0.0656 \\
$p H^{2}$ & 0.6545 & 0.9823 & 0.8489 & 0.0915 \\
$R^{2}$ & 87.9056 & 83.8294 & 52.4266 & 60.7536 \\
\hline
\end{tabular}

${ }^{*} p$ value $<0.05$, indicate that there is a significant incidence. 
Table 4. Experimental validation.

\begin{tabular}{ccc}
\hline Response variable & Predicted value & Observed value \\
\hline Protein $(\mathrm{mg} / \mathrm{mL})$ & 1.44 & 1.83 \\
Degree of hydrolysis $(\%)$ & 17.14 & 17.49 \\
\hline
\end{tabular}


Table 5. Nitrogen content in the chicken bone meal and hydrolysate phases.

\begin{tabular}{lc}
\hline \multicolumn{1}{c}{ Sample } & Nitrogen content (g) \\
\hline Chicken bone meal & 1.58 \\
Hydrolyzed & 1.00 \\
\hline
\end{tabular}


Table 6. Antioxidant content of the hydrolysate before and after glycation.

\begin{tabular}{lcc}
\hline \multicolumn{1}{c}{ Sample } & ABTS & ORAC \\
& $(\boldsymbol{\mu M o l}$ ETrolox/L) & $(\boldsymbol{\mu M o l ~ E T r o l o x / L )})$ \\
\hline Hydrolyzed & $6988.41^{\mathrm{a}}$ & $11683.61^{\mathrm{a}}$ \\
Glycated & $6727.54^{\mathrm{b}}$ & $12450.92^{\mathrm{b}}$ \\
\hline
\end{tabular}

${ }^{a, b}$ Values with different letters are significantly different from each other $(P<0.05)$. 